\title{
PEMBERDAYAAN MASYARAKAT SEBAGAI UPAYA MENCIPTAKAN GENERASI MUDA BERDAYA LITERASI PADA KAMPUNG SINAU KOTA MALANG
}

\author{
Oleh : Nastiti Novitasari \\ Pendidikan Masyaakat, FKIP Universitas Siliwangi, Kota Tasikmalaya \\ e-mail: Nastiti@unsil.ac.id
}

\begin{abstract}
Abstrak: Angka partisipasi sekolah di kota Malang tidak sepenuhnya berjalan dengan baik, dibuktikan dari survei dari tahun 2012 hingga 2018 APS belum 100\% terpenuhi, artinya masih ada anak putus sekolah, termasuk di Cemorokandang Kota Malang masih ada beberapa anak yang mengalami putus sekolah, Kenyataan ini sangat bertentangan dengan keadaan Ideal yang seharusnya, terutama pada bidang literasi. Untuk menghadapi permasalahan, banyak hal yang dapat diterapkan dalam proses pendidikan, baik itu dari jalur formal nonformal maupun informal. Kampung sinau merupakan salah satu kampung tematik yang berada di kawasan Cemorokandang Kota Malang. Kegiatan belajar dilaksanakan dengan unik yang dapat menarik generasi muda khususnya, untuk mengurangi angka putus sekolah dan memperkaya khasanah literasi, menjadikan masyarakat berdaya literasi, dikemas dengan kegiatan pemberdayaan masyarakat. Oleh karena itu, peneliti tertarik untuk mengetahui bagaimana tahapan pemberdayaan masyarakat untuk menjadikan generasi muda berdaya literasi di kampung Sinau. Pendekatan dan jenis penelitian yang digunakan oleh penelliti yakni pendekatan kualitatifjenis studi kasus. Peneliti melaksanakan proses penelitian secara mendalam melalui penelitian deskriptif kualitatif dengan jenis studi kasus. Penelitian ini dilaksanakan pada akhir tahun 2019 di Kampung Sinau Kota Malang. Hasil dari penelitian ini: 1) Inovator tidak harus memiliki pendidikan yang tinggi, 2) Partisipasi masyarakat sangat dibutuhkan dalam keberhasilan program pemberdayaan. 3) Tahapan pemberdayaan yang dilakukan untuk membuat masyarakat berdaya literasi yakni: a) Mengenali lingkungan/wilayah, sasaran dan permasalahan; b) Mengajak dengan pendekatan dan Inovasi yang bisa diterima sasaran; c) Proses pemberdayaan berdasar minat masyarakat dan pengembangan relasi; d) Pemandirian, dengan apresiasi melalui kegiatan-kegiatan. 4) Diperlukan kerjasama dari berbagai pihak dan inovasi untuk menciptakan masyarakat khususnya generasi muda menjadi berdaya literasi. 5) Untuk menciptakan masyarakat berdaya literasi dibutuhkan lingkungan yang mendukung, sarana dan prasarana belajar tersedia.
\end{abstract}

Kata Kunci: pemberdayaan masyarakat, literasi, Kampung Sinau. 


\title{
COMMUNITY EMPOWERMENT AS AN EFFORT TO CREATE A YOUNG GENERATION WITH LITERATIVE POWER IN KAMPUNG SINAU, MALANG CITY
}

\begin{abstract}
The School Participation Rate in Malang City is not fully running well, as evidenced by the survey from 2012 to 2018 the APS has not been 100\% fulfilled, meaning that there are still school dropouts, including in Cemorokandang, Malang City, there are still some children who have dropped out of school. contrary to the ideal condition that should have been. To deal with problems, many things can be applied in the educational process, both from formal, non-formal and informal channels. Kampung Sinau is a thematic village located in the Cemorokandang area of Malang City. Learning activities are carried out in a unique way that can attract the younger generation in particular, to reduce dropout rates and enrich literacy, making people literate, packed with community empowerment activities. Therefore, researchers are interested in knowing how the stages of community empowerment are in making young people literate in Kamoung Sinau. The approach and type of research used by the researcher is a qualitative approach to the type of case study. The researcher carried out the in-depth research process through qualitative descriptive research with the type of case study. This research was conducted at the end of 2019 in Sinau Village, Malang City. The results of this study 1) Innovators do not have to have high education. 2) Community participation is needed in the success of the empowerment program, 3) The stages of empowerment are carried out to make the community literate, namely a) Recognizing the environment / area, targets and problems b) Inviting with acceptable approaches and innovations to the target c) The empowerment process based on interests community and relationship development d) Independence, with appreciation through activities. 4) It takes cooperation from various parties and innovation to create a society, especially the younger generation, to become literate. 5) To create a literate society, a supportive environment is needed, learning facilities and infrastructure are available
\end{abstract}

Keywords: Community Empowerment, Literacy, Kampung Sinau

\section{PENDAHULUAN}

Pendidikan merupakan kebutuhan utama bagi setiap individu dan merupakan suatu proses yang mengarahkan individu menuju kunci kesuksesan dalam hidupnya. Sesuai dengan pendapat dari Plato dalam (Topata, 2020), "Pendidikan adalah sesuatu yang dapat membantu perkembangan individu dari jasmani dan akal dengan sesuatu yang dapat memungkinkan tercapainya sebuah kesempurnaan". Kesempurnaan yang di dapat setiap individu memiliki ranah dan tingkat yang berbeda, sesuai dengan tujuan yang diinginkan oleh individu tersebut. Oleh karena hal tersebut, pemerintah mewajibkan menempuh pendidikan minimal 9 tahun dan boleh lebih dari itu.
Berdasarkan jalurnya, pendidikan dibagi menjadi Pendidikan Formal, nonformal dan Informal. Hal ini telah dijelaskan pada UU Nomor 20 Tahun 2003 tentang Sistem Pendidikan Nasional yakni "Jalur Pendidikan terdiri atas Pendidikan Formal, nonformal dan Informal yang dapat saling melengkapi dan memperkaya." Dalam prosesnya, Ketiga jalur teresebut memiliki peranan masing-masing. Salah satunya Pendidikan Nonformal, yang berfungsi sebagai pengganti maupun pelengkap pendidikan formal.

Tidak semua individu mendapatkan kesempatan mengenyam pendidikan Formal, namun tidak berarti Individu tersebut menjadi Individu yang kurang beruntung. Banyak cara yang 
bisa dilakukan untuk memperoleh pendidikan, bahkan bagi mereka yang sudah menempuh pendidikan formal juga dapat melengkapi pendidikan dengan jalur yang lain, karena pada hakikatnya setiap individu merupakan pemeran utama life long learning yakni menjadi pembelajar sepanjang hayat. Hal tersebut mengandung makna bahwa belajar bisa dilakukan oleh siapa saja, di mana saja, dan kapan saja.

Dalam prosesnya, Pendidikan selalu berkaitan erat dengan kegiatan membaca. Baik dari jalur formal, nonformal maupun Informal, kegiatan ini selalu menjadi salah satu poin utama yang mendukung lancarnya proses pendidikan. Kemampuan membaca ini sering kita sebut dengan kegiatan Literasi. Secara definisi Literasi adalah kemampuan seseorang dalam hal membaca dan menulis. Penguasaan Literasi menjadi salah satu Indikator mencapai kesuksesan, karena dengan penguasaan Literasi, individu dapat memiliki wawasan yang luas, cerdas berbudaya dan menjadi modal SDM unggul bagi bangsa. Sejalan dengan pernyataan tersebut, tanpa literasi maka suatu bangsa ataupun manusia akan kesulitanmemastikan untuk tetap bertahan hidup selayaknya sebagai manusia (Irvansyah, 2018).

Kenyataan yang dihadapi oleh Indonesia selama ini adalah penguasaan literasi yang masuk dalam golongan rendah, hal ini dibuktikan dari hasil survei Programme for International Student Assessment (PISA). Survei yang dilaksanakan pada tahun 2018 menunjukkan, bahwa nilai kompetensi Membaca/literasi, Negara Indonesia ada dalam posisi peringkat 72 dari 77 negara. Tentunya kenyataan ini sangat bertentangan dengan keadaan ideal yang seharusnya dan cukup memprihatinkan. Untuk menghadapi permasalahan ini, banyak hal yang dapat diterapkan dalam proses pendidikan, baik itu dari jalur formal nonformal maupun informal.

Pada jalur nonformal, pengembangan kemampuan literasi dapat dilakukan di luar sistem persekolahan, salah satunya dengan mendobrak semangat generasi muda untuk mencintai dan terus mengasah kemampuan literasi melalui caracara yang dapat diterima sesuai dengan gaya dan kebiasaan mereka. Generasi Muda adalah calon pengganti dari generasi terdahulu, dalam hal ini berumur antara 18 s.d. 30 tahun, dan kadangkadang sampai umur 40 tahun. (Hasibuan, 2008). Menurut WHO (World Healt Organization) mendefinisikan pemuda (generasi muda) adalah seorang dengan usia 10 s.d. 24 tahun. Oleh karena hal tersebut, generasi muda menjadi sasaran utama dari usaha berdaya literasi di Kampung Sinau, generasi muda merupakan modal utama bangsa untuk mewarisi peran memajukan bangsa dan negara.

Dari survei awal yang dilakukan, peneliti memperoleh data dari Badan Pusat Statistik Kota Malang tentang Angka Partisipasi Sekolah tahun 2018 Usia 14-15 Tahun 95,52\% dan usia 16-18 tahun $83,41 \%$. Dilihat dari hasil survei ini, masih ada anak usia sekolah (pemuda) di Kota Malang yang tidak berpatisipasi mengikuti sekolah, (putus sekolah, tidak sekolah). Beberapa diantaranya terdapat di Kawasan Cemorokandang Kota Malang. Dari permasalahan ini, terlihat kesenjangan yang terjadi antara kondisi masih adanya anak putus sekolah dan keadaan tuntutan perkembangan zaman yang mengharuskan generasi muda memiliki daya literasi tinggi untuk menghadapi perkembangan zaman. Dari sinilah timbul suatu gerakan yang dilakukan oleh pegiat pendidikan untuk menuntaskan angka putus sekolah dan mengajak para generasi muda mengasah kemampuan literasi, melalui pemberdayaan masyarakat, yakni dengan adanya kegiatan-kegiatan yang dilakukan di kampung tematik "Kampung Sinau Kota Malang".

Pemberdayaan Masyarakat merupakan suatu upayauntukmelakukan perubahan padamasyarakat agar lebih mandiri dengan menggunakan potensi yang ada dalam dirinya. Potensi ini sangat penting karena masyarakat yang berdaya akan terlihat dari adanya perubahan dalam kesejahteraan yang 
dicapainya (Suharto, 2017). Sejalan dengan hal tersebut, pemberdayaan masyarakat suatu upaya untuk meningkatkan harkat dan martabat lapisan masyarakat yang tidak mampu melepaskan diri dari perangkap kemiskinan dan keterbelakangan, agar memapukan dan memandirikan masyarakat (Hadiyanti, 2017).

Kampung Sinau Kota Malang, merupakan salah satu kampung tematik yang berada di kawasan Cemorokandang, Kota Malang, yang melaksanakan proses pembelajaran secara nonformal dan dikemas melalui program pemberdayaan masyarakat. Berbagai kegiatan belajar dilaksanakan dengan cara-cara unik yang dapat menarik warga, generasi muda khususnya, agar memperkaya khazanah berliterasi dan menjadikan warganya berdaya literasi, salah satunya dengan kegiatan pemberdayaan masyarakat. Tidak sedikit pegiat pendidikan yang menyoroti secara positif dengan menjadi penyokong kesuksesan kegiatan literasi yang ada di Kampung Sinau. Pada prosesnya, banyak hal yang dapat dijadikan pembelajaran bagi berbagai pihak, ada kemudahan dan kesulitan yang dialami, terutama bagi pendiri Kampung ini. Sejalan dengan Jurnal yang ditulis oleh Ainul Bariroh, dkk pada tahun 2019 dengan judul Komunitas Kampung Sinau Sebagai Wahana Pemberdayaan Masyarakat Kelurahan Cemorokandang Kecamatan Kedungkandang, Kota Malang, yang menghasilkan kesimpulan ada beberapa tahapan dalam pemberdayaan masyarakat, diantaranya; 1) tahap mengetahui permasalahan, 2) menyadari permasalahan, 3) mengadakan kegiatan-kegiatan sederhana, 4) membangun jaringan atau kerjasama, 5) tahap melaksanakan kegiatan. Oleh karena hal tersebut, peneliti tertarik untuk mengetahui bagaimana tahapan pemberdayaan masyarakat yang dilakukan oleh inovator yang berusia muda dalam mengatasi angka putus sekolah yang masih terjadi di kawasan Cemorokandang hingga menjadikan generasi muda berdaya literasi.

\section{METODE PENELITIAN}

Pendekatan dan jenis penelitian yang digunakan oleh penelliti yakni pendekatan kualitatif jenis studi kasus. Peneliti melaksanakan proses penelitan secara mendalam melalui penelitian deskriptif kualitatif dengan jenis studi kasus melalui kegiatan analisis proses optimalisasi pemberdayaan masyarakat dalam memberantas putus sekolah dan menjadikan generasi muda berdaya literasi di kampung sinau.

Penelitian ini dilaksanakan pada akhir tahun 2019 di Kampung Sinau Cemorokandang Kota Malang. Sumber data dari penelitian ini berasal dari dua jenis, yakni sumber data manusia yang berasal dari Inovator/pendiri Kampung Sinau, warga setempat khususnya para generasi muda, Pegiat Literasi serta komunitas yang mendukung. Sumber data yang kedua yakni bersumber dari nonmanusia, dokumen-dokumen yang sudah ada, dokumen publikasi, dokumen kegiatan-kegiatan dan arsip tentang proses pendirian Kampung Sinau.

Teknik pengumpulan data yang dilakukan oleh peneliti yakni dengan cara mengumpulkan informasi melalui wawancara secara mendalam dan mengamati kegiatan-kegiatan yang diadakan di Kampung Sinau. Ibrahim (2015: 80) menyebutkan ada 4 teknik yang dapat digunakan untuk pengumpulan data, yakni: (1) observasi, (2) wawancara, (3) dokumentasi dan (4) Focus Group Discussion. Sesuai dengan hal itu, penelitian ini menggunakan ketiga teknik tersebut. Diawali dengan observasi keadaan lingkungan dan wilayah, selanjutnya peneliti mewawancarai secara mendalam narasumber, yakni Inovator (Mansyur), perangkat desa, warga masyarakat sekitar, orang tua peserta didik, komunitas relawan, komunitas literasi, peserta didik, pengunjung. Informasi yang didapat dari hasil wawancara tersebut diantaranya, proses terbentuknya kampung sinau, tanggapan masyarakat dan perangkat desa, tanggapan orang tua peserta didik, Faktor pendukung dan penghambat, tanggapan komunitas tentang 
kampung sinau, hal yang didapatkan peserta didik, tanggapan pengunjung, alasan berkunjung, bagaimana proses tahapan pemberdayaan masyarakat yang dilakukan oleh inovator dalam memberantas angka putus sekolah dan membuat generasi muda menjadi berdaya literasi. Peneliti juga melakukan kegiatan dokumentasi, baik secara langsung maupun dari data-data dokumen yang telah ada, diantaranya arsip dokumentasi tentang Kampung Sinau, kegiatan, program, daftar peserta relawan, komunitas, hasil dokumentasi publikasi penyebaran Kampung Sinau. Peneliti bertindak sebagai partisipan pasif, karena peneliti hanya berperan sebagai pengamat segala kegiatan di Kampung Sinau dan mengumpulkan data melalui wawancara dengan Informan.

Teknik analisis data yang digunakan dalam penelitian ini, yakni analisis data model interaktif. Analisis data interaktif ini sesuai pada konsep yang diungkapkan oleh Miles dan Hubberman dalam Ibrahim (2015:109), yakni terdiri dari kegiatan reduksi data (data reduction), penyajian data (data display), dan penarikan serta pengujian kesimpulan (drawingand verifying conclusion).

\section{HASIL DAN PEMBAHASAN}

\section{Hasil Temuan dan Paparan Lokasi Penelitian}

\section{Keadaan Wilayah}

Kampung Sinau merupakan salah satu dari sekian banyak jenis Kampung Tematik yang berada di Kota Malang, terletak pada kelurahan Cemorokandang Jalan Untung Sudiro RT. 4/RW. 4, Kota Malang. Pada kelurahan Cemorokandang terdapat beberapa jenjang Pendidikan mulai dari TK AL-Ikhlas, Sekolah Dasar Negeri Cemorokandang 1, Sekolah Dasar Negeri Cemorokandang 2, Sekolah Dasar Negeri Cemorokandang 3, Sekolah Dasar Negeri Cemorokandang 4, dan MI Cemorokandang Malang. Tingkat Menengah
Pertama pada kelurahan Cemorokandang terdapat Sekolah Menengah Pertama Negeri 22 Malang, dan Madrasah Tsanawiyah Negeri 2 Malang. Selanjutnya, untuk tingkat menengah atas terdapat SMK Negeri 9 Malang.

\section{Awal Terbentuknya Kampung Sinau}

Kampung Sinau didirikan pada tahun 2012, dari gagasan seorang pemuda warga desa setempat yang bernama Mansyur. M. Toha Mansyur Al Badawi adalah seorang pemuda karang taruna yang pada saat itu masih duduk di kelas 3 SMP, dia merasa prihatin kepada teman-temannya yang berada di desa tersebut karena tidak bisa melanjutkan pendidikan ke sekolah negeri sehingga memilih untuk tidak melanjutkan sekolahnya. Pemuda dengan panggilan akrab Mansyur ini dikenal sebagai pemuda yang ramah dan mudah bergaul sehingga banyak teman-teman yang senang berkumpul di rumahnya. Oleh karena itu, Mansyur memiliki ide untuk mengajak temantemannya belajar bersama di rumahnya. Dia memulai kegiatan belajar dengan memberikan bimbingan belajar secara gratis kepada anakanak dari warga setempat, dengan harapan mereka bisa belajar lebih intensif agar bisa masuk ke sekolah negeri. Di samping hal itu, Mansyur juga mengajak anak-anak belajar berkesenian dan bermain bersama di selasela kegiatan belajar. Hal ini dia lakukan agar menarik minat anak-anak untuk belajar di rumahnya dan mengupayakan mereka agar tidak merasakan jenuh dengan kegiatan belajar yang dia adakan.

\section{Tanggapan tentang Kampung Sinau}

Ide Mansyur sangat diapresiasi dan ditanggapi baikolehwargasetempat. Sepertiyang diungkap oleh salah satu dari perangkat desa yakni Bapak Kepala Desa, mengatakan "saya sangat bangga ada pemuda seperti Mas Mansyur di desa ini, karena bisa mengajak pemuda-pemuda di sini berkegiatan, aktif, dan saya lihat Mas Mansyur ini juga bisa menghidupkan lagi karang taruna 
yang sudah lama tidak aktif, saya harap hal ini terus berjalan, kami mendukung sepenuhnya". Sejalan dengan apa yang diungkapkan oleh ketua RT, masyarakat sekitar juga berpendapat demikian, "sakjoke enek kegiatan deso maleh rame, jadi warga liyane iso oleh keuntungan mbak, kene seng nganggur dadi jogo parkir, dagang, kadang jogo tiket" (sejak ada kegiatan desa jadi rame, jadi warga lainnya bisa dapat keuntungan mbak, yang pengangguran bisa jaga parkiran, dagang, kadang juga jaga tiket).

Meskipun begitu, sempat ada beberapa pihak yang kurang menyetujui kegiatan tersebut dikarenakan beberapa hal, diantaranya anakanak mereka yang biasa membantu pekerjaan menjadi beralih dengan alasan belajar bersama di rumah Mansyur. Namun, seiring berjalannya waktu kegiatan ini dapat diterima dengan baik. Orang tua anak-anak tersebut membutuhkan pembiasaan dan pengertian yang tak hentihentinya disuarakan oleh Manyur. Pendapat sejalan juga diungkapkan oleh relawan dari komunitas pegiat literasi Kota Malang, "Saya tertarik dengan Kampung Sinau ini, karena dengan semangat para pemuda yang luar biasa terutama Mansyur, semangat dan ideidenya patut saya acungi jempol. Bangga bisa bekerjasama dengan mereka”.

\section{Faktor Pendukung dan Penghambat}

Pada setiap kegiatan selalu ada dua faktor yang turut andil dalam prosesnya, yakni faktor pendukung dan penghambat. Dari hasil wawancara yang dilakukan oleh peneliti kepada Mansyur (Inovator), terdapat faktor pendukung dari kegiatan yang dilaksanakan oleh Mansyur dan kawan-kawannya di Kampung Sinau, yakni: 1) Banyaknya relasi (komunitas) yang turut berpartisipasi membantu menyumbangkan ide-ide dan membantu pelaksanaan kegiatan, 2) Antusias masyarakat terhadap hal-hal baru, 3) Dukungan dari perangkat desa, 4) Dukungan dari masyarkat dengan menyediakan lahan untuk terselenggaranya kegiatan. Selain faktor pendukung, terdapat beberapa hal yang menjadi kendala, diantaranya: 1) Dukungan materil untuk memfasilitasi peserta didik masih dirasa kurang, 2) Kepengurusan yang masih tidak tersusun sistematis. 3) Pengaturan jadwal kegiatan, terkadang masih berbenturan antara satu kegiatan dengan kegiatan lainnya.

Meskipundemikian Mansyurdankawan-kawan selalu berusaha mengatasi segala hambatan yang ada, dengan memusyawarahkan dengan semua yang terlibat dalam kepengurusan.

\section{Tahapan Pemberdayaan dalam menjadikan Masyarakat Berdaya Literasi}

Pada tahun 2015 lahirlah nama Kampung Sinau dan diresmikan oleh Kepala Kelurahan serta Ketua RW 4 Desa Cemoro Kandang. Nama Kampung Sinau digagas sendiri oleh Mansyur, menurut dia nama ini tiba-tiba saja terlintas di pikirannya tanpa memiliki maksud meniru kampung-kampung tematik yang sudah ada. Arti dari nama Kampung Sinau menurut Mansyur yakni, menggambarkan kegiatan yang dilakukan di sana, kegiatan sama-sama belajar atau melakukan proses pembelajaran secara bersama-sama di suatu kampung.

Kampung Sinau ini terbentuk berawal dari rasa prihatin Mansyur melihat kenyataan bahwa di daerahnya masih ada anak putus sekolah. Berbagai sebab melatarbelakangi mengapa anak-anak tersebut putus sekolah. Diantaranya, karena tidak diterima di sekolah negeri pilihannya, mereka memutuskan untuk tidak sekolah, alasan yang lain sebab mereka lebih memilih bekerja membantu orang tua bekerja, yang mayoritas adalah seorang petani, dan peternak. Melihat hal ini, Mansyur tergerak untuk memberikan bimbingan belajar kepada anak-anak usia sekolah secara gratis, dengan 
harapan mereka dapat melanjutkan sekolah, mengisi waktu luang anak-anak yang putus sekolah, serta memberikan kesempatan anakanak yang putus sekolah untuk tetap belajar.

Melihat data dari BPS (Badan Pusat Statistik) dalam perhitungan APS (Angka partisipasi sekolah) di Kota Malang pada tahun 2012, terlihat angka partisipasi paling rendah ditunjukkan pada anak usia 16-18 tahun, dengan persentase $74,15 \%$. Usia tersebut termasuk dalam golongan pemuda. Kawasan Cemorokandang termasuk penyumbang angka anak putus sekolah dari persentase tahun tersebut.

Seiring berjalannya waktu, usaha Mansyur memberantas angka putus sekolah mulai terlihat membuahkan hasil, beberapa dari anak-anak putus sekolah mulai terlihat antusias mengikuti bimbingan belajar yang diadakan oleh Masnsyur.

Setelah diresmikan kegiatan di Kampung Sinau semakin beragam, banyak kegiatan sosial dan kesenian yang dilakukan disela-sela kegiatan bimbingan belajar, hingga kegiatan di Kampung Sinau menjadi salah satu program kerja karang taruna desa Cemorokandang yang pada saat itu mulai aktif kembali setelah vakum beberapa saat. Karang Taruna diketuai sendiri oleh Mansyur dan sempat mendapat dukungan dari perangkat desa. Mansyur memberikan motivasi dan memberdayakan para pemuda yang ada di kampung tersebut untuk bekerja sama dengan imbalan Ilmu, pengalaman dan relasi baru. Meskipun bantuan dana yang di dapat masih belum cukup untuk menjalankan program-program yang diusulkan oleh Mansyur, menurutnya jika hanya bantuan dari desa memang tidak cukup untuk melaksanakan kegiatan-kegiatan yang ada. Oleh karena hal tersebut, Mansyur dan teman-temannya mulai mencari donatur untuk kegiatan-kegiatan yang akan dilaksanakan serta memberdayakan warga khususnya para pemuda yang ada di kampung tersebut untuk mendukung kegiatan-kegiatan yang ada di Kampung Sinau.

Sebagai agen penggerak dan inovator, Mansyur terus berusaha agar kegiatan di Kampung Sinau dapat terus berjalan. Selain mencari donatur dan memberdayakan warganya dia juga membuka kesempatan yang diperuntukkan bagi siapa saja yang ingin bergabung untuk menjadi relawan di Kampung Sinau. Rencana Mansyur ini disambut baik oleh temanteman relasinya, hal ini dibuktikan dengan banyaknya relawan yang ingin mengajar dan memberikan ketrampilan anak-anak di desa Cemorokandang tersebut. Relawan yang bersedia membantu berasal dari berbagai Universitas bahkan pegiat seni setempat.

Seiring berjalannya waktu Mansyur tetap mengusahakan agar ide-idenya tetap berjalan dan berkembang. Mansyur melakukan berbagai upaya untuk membuat Kampung Sinau dikenal oleh khalayak umum, dengan mengadakan berbagai kegiatan, diantaranya kegiatan seni, pelatihan, penyuluhan, pemberdayaan hingga pameran hasil karya dari warga belajarnya, demi memotivasi warga belajarnya agar merasa diapresiasi dan dihargai. Mansyur juga membuka donasi buku bagi siapa saja yang ingin memberikan sumbangan buku dari berbagai pihak.

Kampung Sinau sempat masuk dalam nominasi kampung tematik pada ajang perlombaan kampung tematik Kota Malang, namun Kampung Sinau masih belum mendapat apresiasi tinggi dari seluruh masyarakat Kota Malang, dalam arti masyarakat luas masih belum mengenal Kampung Sinau, hal ini merupakan tantangan besar bagi Mansyur pada saat itu. Berbagai usaha dilakukan oleh Mansyur, hingga pada tahun 2017 media publik mulai tertarik dan mengapresiasi kegiatan yang ada di Kampung Sinau. Berita tentang Kampung Sinau akhirnya sering dimuat pada surat kabar baik cetak maupun online. 
Kampung Sinau dikelola oleh Inovator yakni Mansyur, bersama rekan-rekannya yang terbentuk dalam suatu sistem kepengurusan inti yang terdiri dari ketua, wakil, sekretaris dan bendahara. Kampung Sinau memiliki visi dan misi yang dibentuk oleh Mansyur dan rekanrekannya tersebut. Visi misi Kampung Sinau yakni, "Menjadi wahana bagi anak-anak untuk mendapat pembelajaran tambahan sehingga ujung dari progam ini mencetak anak-anak yang siap bersaing dengan tantangan di masa mendatang dan memiliki akhlak yang mulia dengan pengajaran pendidikan karakter"

\section{Program Kegiatan Kampung Sinau}

Kegiatan yang ada di Kampung Sinau ini antara lain, (1) Program Bimbingan Belajar, (2) Kegiatan berkarya seni, (3) Pameran Karya (Semangart), (4) Festival Budaya, (5) Pelangi Nusantara. Dari kelima kegiatan tersebut, ada beberapa kegiatan yang merujuk pada kegiatan pemberdayaan, yakni Kegiatan Berkarya Seni dan Pameran Karya. Dalam kegiatan ini Mansyur mengadakan pelatihan karya untuk warga setempat khususnya para pemuda di Kampung Sinau untuk mengikuti berbagai pelatihan, diantaranya pelatihan membuat benda-benda bernilai jual dari barang bekas, membuat lukisan, dan lain sebagainya. Kegiatan tersebut dibimbing oleh pegiat seni, relawan dan komunitas-komunitas yang mendukung. Setelah melaksanakan kegiatan tersebut, diadakan pendampingan bagi peserta untuk melaksanakan pameran hasil karya mereka dengan memberi label nilai jual bagi hasil karyanya.

Kegiatan Pameran ini mulai dikenal dan mendapat apresiasi dari berbagai pihak. Banyak pengunjung yang mendatangi Kampung Sinau untuk melihat pameran. Tidak sedikit dari mereka yang berasal dari luar kota, dan tentunya media sosial dan relawan publikasi sangat berperan dalam hal ini. Beberapa karya yang terjual pada pameran ini disumbangkan untuk kemajuan kegiatan literasi yang ada di Kampung Sinau. Yakni, dengan menambah koleksi buku-buku yang ada di Perpustakaan Kampung sinau.

Perpustakaan ini adalah Icon utama Kampung Sinau, dengan ruang seadanya perpustakaan didirikan senyaman mungkin dan didesain semenarik mungkin oleh para relawan komunitas, salah satunya komunitas Mural yang menghias ruangan menjadi lebih nyaman dan dengan hiasan-hiasan lukisan dinding yang iconic, dengan tujuan semakin banyak pengunjung perpustakaan dan mendobrak semangat para pengunjung untuk gemar membaca.

Peserta pelatihan yang karyanya dipamerkan telah mendapat ilmu baru dan dapat melakukan kegiatan yang diperoleh saat pelatihan untuk menghasilkan barang-barang dengan nilai jual guna menambah pendapatan mereka. Tidak hanya itu, masyarakat sekitar juga mendapat kesempatan untuk memiliki profesi sampingan, yakni menjadi tim penjaga kendaraan pengunjung atau tukang parkir di setiap kegiatan yang ada di Kampung Sinau. Hal ini juga dapat menambah pemasukan dalam hal perekonomian bagi warga setempat.

Oleh karena semakin banyak khalayak pemuda yang berminat mengikuti kegiatan di Kampung Sinau, khususnya pelatihan karya benilai jual, Manysur dan rekan-rekannya memiliki ide untuk mengadakan pelatihan dan pameran secara rutin yang terjadwal. Dengan adanya kegiatan ini Mansyur dan rekan-rekannya telah mengajak banyak para warga khususnya pemuda menjadi berdaya, berdaya dalam hal meningkatkan kemandirian perekonomian serta berdaya dalam literasi, karena kegiatan ini ditujukan untuk menarik minat mereka berkunjung ke Perpustakaan Kampung Sinau serta menjadi partisipan dalam perkembangan literasi di Kampung Sinau. 
Setiap kegiatan yang ada di Kampung sinau, memiliki tujuan utama pada kegiatan literasi. Selain kegiatan Pelatihan, Pendampingan dan Pameran Karya tersebut, Kampung Sinau juga memiliki kegiatan lain yang tak kalah menarik, yakni Festival Budaya dan Pelangi Nusantara yang rutin terjadwal di setiap tahunnya. Kegiatan ini merujuk pada kegiatan berkesenian, diantaranya pertunjukan tari, musik dan kegiatan seni lainnya. Peserta kegiatan ini tidak lain adalah peserta dari beragam pelatihan yang diadakan Kampung Sinau.

Respon positif dan dukungan selalu diperoleh Mansyur dan rekan-rekannya dalam kegiatan Festival Budaya dan Pelangi Nusantara ini, Kedua kegiatan ini juga diperuntukkan pada pengembangan literasi di Kampung Sinau. Mansyur memberikan kesempatan bagi pengunjung untuk menjadi donatur perpustakaan Kampung Sinau, dengan cara mewajibkan tiket masuk berupa satu buku untuk satu orang pengunjung. Hal ini dirasa sangat efektif untuk memperbanyak tambahan ilmu pengetahuan melalui buku-buku tersebut.

Dari kegiatan ini, semangat belajar masyarakat menunjukkan kenaikan secara dinamis. Angka putus sekolah di kawasan Kampung Sinau mulai berkurang, tercatat hingga tahun 2018 selalu mengalami peningkatan, hingga anakanak yang diterima di sekolah negeri sesuai keinginanpun mengalami peningkatan. Selain hal itu, kegiatan berliterasipun tidak mau kalah, warga mulai terbiasa dengan kegiatan membaca buku, mengikuti pelatihan dan kegiatan pendidikan yang ada di Kampung Sinau.

\section{Pembahasan}

Dari hasil paparan data yang telah diperoleh, peneliti mengkaji berbagai hal, diantaranya kegiatan-kegiatan yang dilakukan oleh penggerak Kampung Sinau, yakni kegiatan nonformal yang dikemas dalam kegiatan pemberdayaan yang dapat menunjang perkembangan Literasi, menjadikan individu maupun kelompok pengunjung Kampung Sinau menjadi berdaya literasi. Hal tersebut dibuktikan dari meningkatnya pengunjung Perpustakaan Kampung Sinau untuk membaca dan melaksanakan kegiatan pelatihan di lokasi tersebut serta semakin berkembanganya perpustakaan Kampung Sinau, hal ini dapat dilihat dari banyaknya buku yang diperoleh, berita-berita di media massa yang memuat ulasan tentang Kampung Sinau, hingga menyulap ruangan sederhana menjadi perpustakaan nyaman untuk proses belajar.

Dari penelitian ini, diperoleh sebuah pembahasan tentang pemberdayaan dan partisipasi masyarakat yang mendukung masyarakat menjadi berdaya literasi. Hal ini, didukung oleh penelitian terdahulu melalui jurnal oleh Taufik Akbar dan Faqih Alfian tahun 2018 dengan judul Kampung Tematik sebagai Bentuk Partisipasi Masyarakat dalam Permasalahan Permukiman Kumuh di Kota Malang, jurnal ini membahas tentang peran partisipasi mayarakat, yang menghasilkan kesimpulan partisipasi masyarakat berpengaruh dalam mengatasi pemukiman kumuh yang ada di Kota Malang.

Tahapan pemberdayaan masyarakat menurut Wilson dalam (Mardikanto, 2017) mengemukakan bahwa kegiatan pemberdayaan pada setiap individu dalam suatu organisasi, merupakan suatu siklus kegiatan yang terdiri dari: (1) Menumbuhkan keinginan pada seseorang untuk berubah dan memperbaiki titik awal perlunya pemberdayaan, (2) Menumbuhkan kemauan dan keberanian untuk melepas diri dari kesenangan/ kenikmatan dan hambatan-hambatan yang dirasakan, (3) Mengembangkan kemauan untuk mengikuti atau mengambil bagian dalam kegiatan pemberdayaan yang memberikan manfaat atau perbaikan keadaan, (4) peningkatan peran atau partisispasi dalam 
kegiatan pemberdayaan yang telah dirasakan manfaat/perbaikannya, (5) peningkatan peran kesetiaan pada kegiatan pemberdayaan, (6) peningkatan efektivitas dan efisiensi kegiatan pemberdayaan, (7) Peningkatan Kompetensi untuk melakukan perubahan melalui kegiatan pemberdayaan baru.

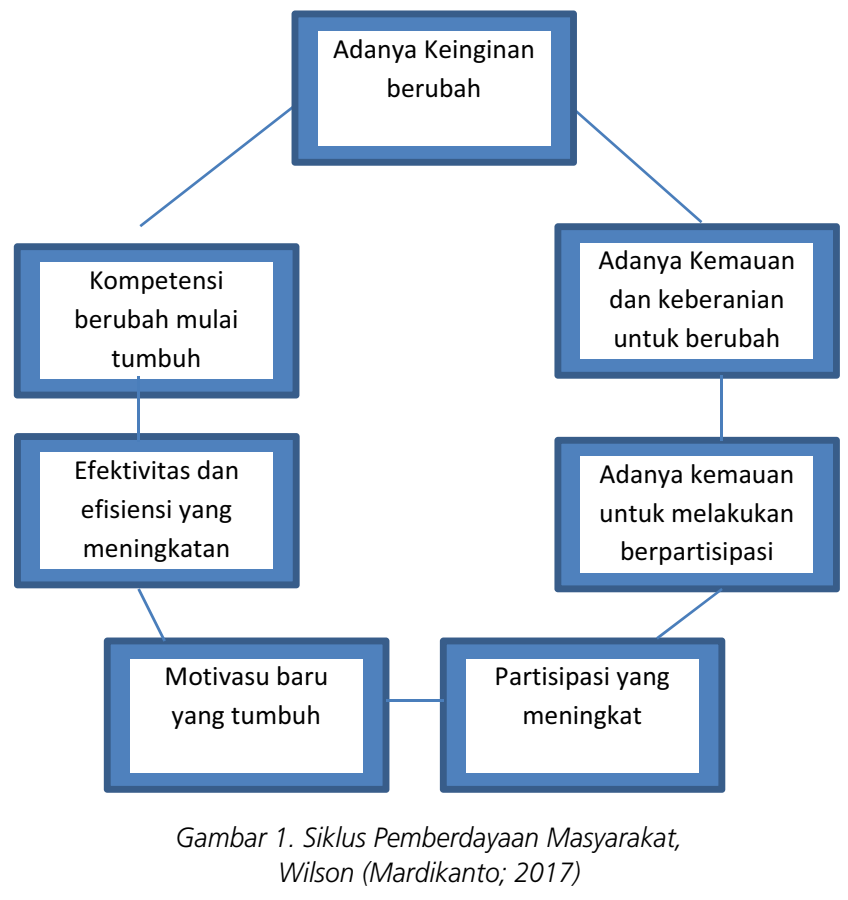

Tahapan menurut Tim Delivery dalam (Mardikanto, 2017) yakni: (1) Menyeleksi atau melakukan survei pada lokasi/Wilayah, (2) Memberikan sosialisasi Pemberdayaan kepada Masyarakat, (3) Proses Pemberdayaan Masyarakat, (4) Proses memandirikan Masyarakat. Sejalan dengan pendapat Tim Delivery, tahapan pemberdayaan yang dilakukan pada Kampung Sinau dalam menjadikan Masyarakat Berdaya Literasi adalah: 1) Identifikasi wilayah yang dilakukan oleh inovator, dalam hal ini Mansyur sebagai Inovator, pemuda penggerak Kampung Sinau melihat keadaan di desanya yang cukup memprihatinkan, ada beberapa anak yang putus sekolah serta tingkat keinginan belajar pemudapemuda yang ada masih sangat rendah. 2) Pada tahap selanjutnya Mansyur mulai mendobrak semangat warganya, khususnya para pemuda untuk mengikuti berbagai kegiatan belajar yang dikemas secara menarik sesuai dengan minat dan bakat para pemuda. Tanpa lelah Mansyur melakukan sosialisasi kepada warganya untuk dapat berpartisipasi dalam hal ini. 3) Pada prosesnya Mansyur merangkul segala bentuk relasi, baik dari komunitas maupun relawan agar warga berminat untuk berpartisipasi dan berkembang hingga ke luar daerah desanya. Mansyur dan tim penggerak lainnya mengadakan kegiatan-kegiatan yang dapat memberdayakan setiap peserta maupun pemuda-pemuda dari desanya. Berdaya dari segi ekonomi, hingga berdaya dalam hal literasi, menurutnya selama pemuda-pemuda giat melakukan kegiatan di kampungnya, dia yakin keinginan menjadikan mereka berdaya literasi pasti tercapai. 4) Pada proses pemandirian, Mansyur dan tim penggerak lainnya melakukan pendampingan untuk mengapresiasi hasil dari belajar para peserta kegiatan di Kampung Sinau. Apresiasi ini cukup signifikan menarik dan mendobrak semangat para peserta untuk menjadi masyarakat yang berdaya, secara ekonomi dan literasi.

Dalam hal ini partisipasi masyarkat merupakan salah satu kunci utama keberhasilan programprogram yang diadakan oleh Tim Kampung Sinau dalam menjadikan warga dan peserta menjadi berdaya. Sesuai dengan Jurnal yang ditulis oleh Nisa Hafizhitus Syarifa dan Atika Wijaya dengan judul Partisipasi Masyarakat dalam Kegiatan Pemberdayaan melalui Program Kampung Tematik (Studi Kasus di Kampung Batik Kelurahan Rejomulyo Kecamatan Semarang Timur Kota Semarang) tahun 2019 yang menghasilkan beberapa kesimpulan, salah satunya adalah disebutkan bahwa Keberhasilan Pemberdayaan Masyarakat dapat dilihat dari partisipasi masyarakat.

Selanjutnya, dari Jurnal yang ditulis oleh Hutri Agustino pada tahun 2019 dengan judul 
Pemberdayaan Masyarakat Berbasis Gerakan Literasi di Taman Baca Masyarakat Pondok Sinau Lentera Anak Nusantara, menyebutkan bahwa kesimpulan dari penelitiannya yakni: (1) Eksistensi pemberdayaan berbasis gerakan literasi di Pondok Sinau Lentera Anak Nusantara sebagai jawaban atas problematika sosial-historis wilayah desa; (2) Realisasi pemberdayaan dilaksanakan berdasarkan prinsip kesukarelaan (voluntarism) dan kemandirian (independence); (3) Fokus utama dari kegiatan pemberdayaan adalah transformasi nilai-nilai karakter (character building) utamanya bagi kelompok usia produktif serta mendorong kemandirian sosialekonomi berbasis rangkaian kegiatan soft skill tematik. Hal ini sejalan dengan keadaan yang ada di Kampung Sinau, realisasi pemberdayaan dilaksanakan secara sukarela oleh para relawan yang ingin bergabung membantu terwujudnya masyarakat yang berdaya literasi. Selain ditujukan untuk peserta secara tidak langsung, para relawan juga turut menjadi masyarakat yang berdaya literasi, dibuktikan dengan strategi para relawan untuk mengajak masyarakat menjadi gemar belajar diawali dengan turut sertanya relawan dalam kegiatan tersebut. Fokus utama dari kegiatan di Kampung Sinau ini ditujukan untuk warga masyarkat yang tergolong generasi muda, yakni pemuda-pemudi yang ada di Desa tersebut serta para peserta lain dari luar daerah tersebut, meskipun dengan hal itu tidak menutup kemungkinan juga kegiatan dilakukan oleh warga di luar usia produktif di Kampung Sinau.

Kegiatan-kegiatan yang ada di Kampung Sinau juga tidak terlepas dari teori-teori pemberdayaan masyarakat diantaranya teori tentang pendekatan dalam pemberdayaan masyarakat. Teori ini didasari dari pendapat Axinn dalam Ibrahim (2015: 159) yang menyebutkan bahwa apa pun pendekatan yang diterapkan, harus memperhatikan: 1)
Tujuan yang ingin dicapai melalui kegiatan pemberdayaan. 2) Sistem transfer teknologi yang akan dilakukan. 3) Pengembangan sumber daya manusia/fasilitator yang akan melakukan pemberdayaan. 4) alternatif organisasi pemberdayaan yang akan diterapkan. Dari pendapat tersebut kegiatan di Kampung Sinau juga menerapkan hal yang sama, yakni: 1) Tujuan yang ingin dicapai dari kegiatan pemberdayaan yang dilakukan oleh Mansyur dan tim penggerak lainnya adalah menjadikan warganya khususnya para generasi muda menjadi berdaya literasi. 2) Cara-cara yang dilakukan sesuai dengan keadaan masa kini, dapat menarik minat para warga/pemuda yang menjadi peserta kegiatan belajar di Kampung Sinau. Diantaranya kegiatan yang selalu di update atau disosialisasikan pada media sosial, memudahkan pemuda-pemudi mengakses dan menerima informasi, jenisjenis kegiatan dimulai dari pameran, hingga festival budaya cukup menarik minat warga/ pemuda berpartisipasi. 3) Mansyur bersama tim juga turut mengikuti kegiatan pelatihan, yang ada di Kampung Sinau. Setiap kegiatan pelatihan biasanya mereka mengundang pegiat pendidikan dari komunitas-komunitas yang menjadi relasi Kampung Sinau. Dengan hal ini, Mansyur dan semua tim turut berpartisipasi menambah ilmu pengetahuan, meningkatkan kemampuan pribadi masing.

Dikaji dari usia Mansyur yang pada saat itu masih sangat muda, yakni 15 tahun, ide-ide Mansyur cukup membawa perubahan besar pada masyarakat sekitarnya. Mansyur telah berhasil berkontribusi meningkatkan APS (Angka Partisipasi Sekolah) di daerahnya, memotivasi anak-anak putus sekolah agar tetap belajar, dan melanjutkan sekolahnya. Di samping itu Mansyur telah mengadakan kegiatan pemberdayaan masyarakat yang berimbas pada meningkatnya kemampuan literasi warganya. Berdaya dalam hal ekonomi maupun literasi. 


\section{PENUTUP}

Dari penelitian ini dapat diperoleh kesimpulan: 1) Inovator tidak harus memiliki pendidikan yang tinggi, dibuktikan oleh Mansyur yang pada saat membentuk Kampung Sinau, usianya masih 15 Tahun, dan duduk di bangku Sekolah Menengah Pertama. 2) Partisipasi masyarakat sangat dibutuhkan dalam keberhasilan program pemberdayaan, 3) Tahapan pemberdayaan yang dilakukan untuk membuat masyrakarat berdaya literasi yakni: a) Mengenali lingkungan/wilayah, sasaran dan permasalahan, b) Mengajak dengan pendekatan dan Inovasi yang bisa diterima sasaran, c) Proses pemberdayaan berdasar pada minat masyarakat dan pengembangan relasi, d) Pemandirian dengan apresiasi melalui kegiatankegiatan,4) Diperlukan kerjasama dari berbagai pihak dan inovasi untuk menciptakan masyarakat khususnya generasi muda menjadi berdaya literasi, dan 5) Untuk menciptakan masyarakat berdaya literasi dibutuhkan lingkungan yang mendukung, sarana dan prasarana belajar tersedia.

\section{DAFTAR PUSTAKA}

Direktoran Pendidikan dan Kebudayaan. (2005). Undang-undang Sisdiknas No. 20 Tahun 2003 Tentang Sistem Pendidikan Nasional. Surabaya: Media Centre

Hasibuan, Malayu. (2008). Manajemen Sumber Daya Manusia. Jakarta: PT. Bumi Aksara.

Ibrahim. (2015). Metodologi Penelitian Kualitatif. Bandung: Alfabeta.

Kompas.com. (05 April2020). diakses dari https://edukasi.kompas.com/ read/2020/04/05/154418571/nilai-pisa-siswaindonesia-rendah-nadiem-siapkan-5-strategiini?page=all pada tangga 01 September 2020
Mardikanto, Totok. (2017). Pemberdayaan Masyarakat dalam Prespektif Kebijakan Publik. Bandung: Alfabeta

Novita, Rhyke, dkk. (2018). Statistik Pendidikan Kota Malang. Kota Malang: Badan Pusat Satistik.

Suharto, Edi. (2017). Membangun Masyarakat Memberdayakan Rakyat. Bandung: Refika Aditama

Topata, Jensen (2020). Pengertian Pendidikan. Diakses dari https://www.mypurohith.com/ pengertian-pendidikan/ pada tanggal 27 September 2020

\section{Sumber Jurnal}

Akbar, Taufik, dkk. (2018). Kampung Tematik sebagai Bentuk Partisipasi Masyarakat dalam Permasalahan Permukiman Kumuh di Kota Malang. Unipasby.ac.id.

Agustino, Hutri. (2019). Pemberdayaan Masyarakat Berbasis Gerakan Literasi di Taman Baca Masyarakat Pondok Sinau Lentera Anak Nusantara.Jurnal Sospol UMM.

Bariroh , Ainul. (2019). Komunitas Kampung Sinau Sebagai Wahana Pemberdayaan Masyarakat Kelurahan Cemorokandang Kecamatan Kedungkandang Kota Malang.Jurnal Pendidikan Nonformal UM.

Hadiyanti, Puji. (2017). Studi Deskriptif Peningkatan Literasi Budaya Memelihara Lingkungan di Kota DKI Jakarta. Jurnal Akrab.

Irvansyah, Adi. (2018). Analisis Kemampuan Literasi Ekonomi Kelompok Belajar Keaksaraan Usaha Mandiri di Desa Pabuaran Kecamatan Sukamakmur Bogor Jawa Barat. . Jurnal Akrab.

Syafira, Nisa H, dkk. (2019). Partisipasi Masyarakat dalam Kegiatan Pemberdayaan melalui Program Kampung Tematik (Studi Kasus di Kampung Batik Kelurahan Rejomulyo Kecamatan Semarang Timur Kota Semarang). Jurnal Solidarity Unnes. 